УДК 911.3

\author{
РОЗВИТОК ГЕОГРАФІЧНОЇ НАУКИ У ЛЬВОВІ \\ ЗА РОКИ НЕЗАЛЕЖНОСТІ УКРАЇНИ: СТРУКТУРА, \\ НАУКОВІ ШКОЛИ, ЗДОБУТКИ, ПРОБЛЕМИ
}

\author{
Іван Ковальчук \\ Наџіональний університет біоресурсів і природокористування Украйни, \\ вул. Васильківська, 17, м. Київ, 03040, Украӥна
}

Схарактеризовано передумови розвитку львівської географії у кінці XX-початку XXI ст. і структуру географічних досліджень львівських учених цього періоду. Показано, що траєкторія розвитку визначалася певними чинниками. У структурі географічних досліджень виділено три блоки напрямів. Проаналізовано здобутки і перспективи розвитку чотирьох наукових шкіл. Виокремлено проблемні питання та окреслено перспективні напрями розвитку географічних досліджень у рамках львівської університетської географії.

Ключові слова: львівська географія, наукові школи, структура географічних досліджень, проблеми львівської географії.

Досліджено історію розвитку географії від 1991 р. (проголошення незалежності України) до середини 2012 р. Увага до розвитку української географії львівськими вченими в цей період зумовлена створенням в Україні Інституту географії НАН України (м. Київ); відкриттям у класичних і педагогічних університетах географічних факультетів та кафедр; активізацією різновекторних географічних досліджень України та її регіонів після здобуття нею незалежності; відродженням досліджень у раніше заборонених галузях антропогеографії, політичній географії і геополітиці, географії культури і релігії, суспільній та електоральній географії тощо; проникненням екологічних ідей в усі напрями географічної науки, формування еколого-географічних галузей знань; зміцненням існуючих наукових шкіл і центрів географічної науки України (Київ, Львів, Одеса, Харків, Сімферополь, Чернівці); появою і пришвидшеним розвитком нових географічних осередків (Дніпропетровськ, Вінниця, Тернопіль, Луцьк, Суми, Луганськ, Івано-Франківськ, Кіровоград, Умань, Рівне, Ужгород та ін.); збільшенням набору студентів на географічні, геолого-географічні та природничо-географічні факультети і відповідним зростанням чисельності та якісного складу викладачів, працівників науководослідної сфери, активізацією їхньої науково-дослідної роботи; створенням мережі спеціалізованих Вчених рад із захисту кандидатських і докторських дисертацій та активною їхньою роботою в галузі підготовки кадрів найвищої кваліфікації; розвитком поліграфічної сфери, збільшенням можливостей швидкого опублікування монографій, навчальних посібників, збірників праць, журна-

(C) Ковальчук I., 2013 
лів, статей; поєднанням досвіду вчених старшої генерації, енергії та ініціативи молодих науковців; збільшенням запитів практики на географічні, геоекологічні, геодемографічні, геосоціальні, рекреаційно-туристські знання, пропозиції і рекомендації, на фахівців географічного і геоекологічного профілю; посиленням уваги до історії розвитку географічної науки взагалі й української географії зокрема (публікація низки розвідок з історії української географії такими вченими, як й проф. О. Краснопольський, проф. О. Шаблій, проф. М. Пістун, проф. І. Ковальчук, проф. В. Пащенко, проф. А. Оліферов, проф. С. Позняк, проф. І. Черваньов, проф. Я. Кравчук, проф. О. Заставецька, проф. С. Бортник, проф. Я. Олійник, проф. В. Стецюк, проф. Ж. Матвіїшина, проф. В. Палієнко, проф. М. Костриця, доц. П. Штойко, доц. Б. Муха, доц. П. Чорномаз та ін.

Розглянемо детальніше передумови і чинники, які спричинили суттєвий прогрес у розвитку географічної науки у Львові наприкінці XX-на початку XXI ст., проаналізуємо структуру географічних досліджень та найважливіші їхні результати і проблеми. Через те, що основним (але не єдиним!) осередком географічної науки у Львові $\epsilon$ географічний факультет, акцент нашого дослідження зроблений на аналізі здобутків, перспектив і проблем розвитку саме цього інституційного утворення. У наступній публікації плануємо оцінити роль в її розвитку й інших львівських осередків географії.

Історію розвитку географічної науки у Львові i, зокрема, у Львівському державному (тепер національному) університеті імені Івана Франка широко висвітлено у низці публікацій С. Рудницького [21], А. Ващенка, К. Геренчука, Г. Зільбера, П. Цися [2], А. Ващенка, К. Геренчука, Я. Кравчука, Г. Міллера [3], О. Шаблія [22-25], І. Ковальчука [5-8], І. Ковальчука, Я. Кравчука [9], Я. Кравчука [10-11], Я. Кравчука, Б. Хомина [14], М. Мальської, М. Рутинського [12], А. Мельника, Б. Мухи, О. Федірка [16], Б. Мухи [17], К. Гарасімюк [26], А. Яна [27], Я. Кравчука, С. Позняка, П. Климовича, М. Кіта [13], С. Позняка, О. Бонішко [19], В. Біланюка, С. Іванова [1], М. Влах, Т. Коропецької [4] та ін. $[18,20]$.

Історію розвитку географії також відображено у монографії, присвяченій 350-річчю Львівського національного університету імені Івана Франка. $X X I \mathrm{~cm}$.

Передумови і чинники розвитку львівської географії наприкінці $X X$-початку

Головними передумовами, які спричинили активізацію географічних досліджень у кінці XX ст. та появу нових напрямів, наукових шкіл і постатей $€$ :

- наявність у Львові відомих учених (продовжувачів справи засновників Львівської географії - А. Ремана, Е. Ромера, Г. Величка, С. Рудницького, Ю. Полянського та ін.), а також фундаторів нових наукових шкіл, які багато зробили у 50-70-х роках XX ст. для української географії взагалі і львівської у 80-90-х роках XX ст. До цієї категорії належать, зокрема, П. Ващенко, К. Гечук, П. Цись, Ф. Заставний, О. Шаблій, Г. Міллер, Я. Кравчук, П. Климович, Л. Скварчевська, С. Трохимчук, Г. Проць та ін.; 
- суспільні зміни в Україні після здобуття нею незалежності, які зумовили підвищення попиту на географічні, екологічні, геополітичні, етногеографічні, геокультурні знання і спричинили виникнення нових напрямів досліджень і нових галузей землезнавчої науки;

- інтенсивний розвиток географічного факультету у кінці 80-90-х років XX ст. і першому десятилітті XXI ст. під керівництвом канд. геогр. наук, проф. Я. Кравчука, суттєві зміни у його структурі (замість трьох кафедр сформовано вісім, утворено 10 навчальних і дві науково-дослідні лабораторії, чотири постійно діючі стаціонари - Дністерський, Розтоцький, Чорногірський і Шацький, а також науково-дослідні стаціонари з вивчення сучасних геоморфологічних процесів (Передкарпатський у с. Медвежа, Опільський у с. Білка, Закарпатський у с. Довге, Південно-Розтоцький у с. Дубровиця, Лозина);

- розширення напрямів і спеціальностей з підготовки фахівців на географічному факультеті Львівського національного університету імені Івана Франка (від одного до чотирьох). У реалізації цих завдань велика заслуга проф. Я. Кравчука, який зумів активізувати роботу наявного наукового потенціалу, запросив на роботу відомих учених з інших наукових центрів України (докторів геогр. наук Ф. Заставного, С. Позняка);

- створення двох спеціалізованих вчених рад з захисту докторських (голова проф. Ф. Заставний, тепер - проф. О. Шаблій) і кандидатських (голова проф. І. Ковальчук, пізніше - проф. А. Мельник) дисертацій та розширення набору фахівців в аспірантуру і докторантуру (щорічно від 16 до 25 осіб);

- кількісне та якісне зростання викладацького (від 24 до 107 осіб, з них від трьох до 10-15 докторів і професорів) і науково-дослідницького потенціалу факультету, захист докторських і кандидатських дисертацій географами, які працюють в інших навчальних закладах, науково-дослідних інститутах (Інститут регіональних досліджень НАН України, інститут екології Карпат, інститут "Геопрогноз”, ДП “Державний інститут проектування міст "Містопроект”);

- розвиток та посилення існуючих (суспільної географії, ландшафтознавства, геоморфології), поява нових (географічного українознавства, біогеографії і географії грунтів, палеогеографії антропогену, екологічної та інженерної геоморфології, конструктивної географії, геоекології і гідроекології та ін.) наукових шкіл і напрямів географічних досліджень; налагодження творчих контактів між львівськими географами та географами інших країн (Польщі, Німеччини, Австрії, Франції, США, Словаччини, Угорщини, Росії, Румунії, Швеції);

- інші чинники, зокрема, процеси глобалізації наукового та освітнього простору, участь у виконанні міжнародних дослідницьких проектів, налагодження контактів із зарубіжними університетами тощо.

Структура географічних досліджень львівських учених.

Вона визначається кількома чинниками: 1) традиціями львівської географії, в якій основними напрямами досліджень були природничо-географічні, 
суспільно-географічні і картографічні; 2) впливом інновацій світової географії на розвиток львівської географічної науки; 3) існуючим науковим потенціалом та зростанням; 4) змінами в житті суспільства, його запитами до географічної науки; 4) змінами дослідницького апарату і технологій вивчення навколишнього світу тощо. Структуру географічних досліджень львівських географів у кінці XX-на початку XXI ст. подано у вигляді схем (рис. 1, 2, 3).

Стислий аналіз напрямів творчого пошуку львівських географів дає змогу об'єднати їх у декілька блоків: 1) загально-географічних і суспільногеографічних досліджень; 2) природничо-географічних досліджень; 3) туристично-рекреаційних і природоохоронних досліджень. У кожному з цих блоків виділено від чотирьох до восьми груп дослідницького пошуку, які далі диференціюємо на 8-15 галузей. Найбільшим різноманіттям характеризуються блоки природничо-географічних (83 галузі) та загально-географічних і суспільногеографічних досліджень (68 галузей), дещо меншим - блок туристично-рекреаційних і природоохоронних досліджень (36 галузей). Вважаємо це пов'язано 3 порівняно недавнім виникненням цих двох напрямів досліджень, які мають великий потенціал росту і розвитку.

Оскільки до 350-річного ювілею Львівського університету підготовлена “Енциклопедія Львівського університету”, а до 130-річного ювілею львівської географії опублікований ювілейний, 40-й Вісник Львівського університету, серія географічна (у двох частинах), у яких подано характеристику наукової діяльності кафедр географічного факультету, окремих науковців, випускників факультету, які працюють в інших установах України, то немає потреби стисло аналізувати цей бік функціонування львівської географії у статті. 3 огляду на ці обставини, схарактеризуємо наукові школи - їхній склад і творчу діяльність.

Наукові школи і провідні вчені.

Наукова школа генетичного трунтознавства заснована у 1993 р. на базі Львівського національного університету імені Івана Франка. Засновник - доктор геогр. наук, проф., завідувач кафедри грунтознавства і географії грунтів С. П. Позняк. Представниками наукової школи є доктори наук, проф. В. І. Михайлюк, проф. А. І. Кривульченко, проф. З. Г. Гамкало, проф. В. Г. Гаськевич, проф. М. Г. Кіт, доценти О. І. Єргіна, Б. П. Свидницький, З. П. Паньків, І. Я. Папіш, А. А. Кирильчук, О. Г. Телегуз, Т. С. Ямелинець, Г. С. Підвальна та ін. Серед членів наукової школи 45 кандидатів наук. Представники школи опублікували серію посібників і підручників 3 географії грунтів і грунтознавства (понад десять), монографічну серію "Грунти України" (16 монографій), серію фундаментальних статей у галузі генетичного грунтознавства, географії грунтів, їхнього картографування, біосферних функцій грунтів, режимів грунтових процесів, грунтово-екологічних проблем, оптимізації використання й охорони земель, землеустрою, агробізнесової діяльності та ін.

До перспективних напрямів досліджень цієї школи належать: інструментальні, лабораторні та прогностичні дослідження екологічних функцій грунтів у біосфері і природно-господарських системах; оцінювання стійкості грунтів, їхнього очищувального і відтворювального потенціалу; вивчення режимів 


\begin{tabular}{|c|c|c|}
\hline $\begin{array}{l}\quad \text { демогеографічний } \\
\text { - теоретичні проблеми } \\
\text { демогеографії; } \\
\text { - демогеографія України та її } \\
\text { Західного регіону; } \\
\text { - антропогеографія; } \\
\text { - географія населення України; } \\
\text { - географія населення Західного } \\
\text { регіону і Львівської області; } \\
\text { - географія міських поселень; } \\
\text { - географія розселення } \\
\text { населення; } \\
\text { - історична географія поселень і } \\
\text { розселення; } \\
\text { - геоурбаністика; } \\
\text { - географія трудових ресурсів; } \\
\text { - етногеографія України і ії } \\
\text { Західного регіону; } \\
\text { - топоономастика. }\end{array}$ & $\begin{aligned} & \text { соціогеографічний } \\
& \text { - теоретичні проблеми } \text { соціальної географії; } \\
& \text { - географія сфери послуг; } \\
& \text { - географія релігії } \\
& \text { (сакральна географія); } \\
& \text { - географія освіти; } \\
& \text { - географія соціальних } \\
& \text { негараздів; } \\
& \text { - географія культури; } \\
& \text { - рекреаційна географія; } \\
& \text { - медична географія; } \\
& \text { - географія соціальних } \\
& \text { проблем депресивних } \\
& \text { регіонів; } \\
& \text { - географія конфліктів; } \\
& \text { - географія геноциду, } \\
& \text { голодоморів; } \\
& \text { - географія соціальних } \\
& \text { проблем села. }\end{aligned}$ & $\begin{array}{l}\quad \text { економіко-географічний } \\
\text { - теорія економічної географії; } \\
\text { - теорія розміщення } \\
\text { продуктивних сил; } \\
\text { - теорія територіального } \\
\text { комплексоутворення; } \\
\text { - економічна географія } \\
\text { України; } \\
\text { - географія агропромислових } \\
\text { комплексів; } \\
\text { - географічне країнознавство; } \\
\text { - географія транспорту; } \\
\text { - географія промисловості; } \\
\text { - географія агробізнесу; } \\
\text { - географія прикордоння; } \\
\text { - географічні проблеми } \\
\text { депресивних регіонів; } \\
\text { - географічні дослідження } \\
\text { Єврорегіонів; } \\
\text { - географічне країнознавство. }\end{array}$ \\
\hline $\begin{array}{l}\text { політико-географічний } \\
\text { - теоретичні проблеми } \\
\text { політичної географії і } \\
\text { геополітики; } \\
\text { - політична географія України; } \\
\text { - геополітичні проблеми } \\
\text { України; } \\
\text { - електоральна географія } \\
\text { України та її регіонів. }\end{array}$ & $\begin{array}{c}\text { Напрями суспільно- } \\
\text { географічних досліджень }\end{array}$ & $\begin{array}{l}\text { картографо-географічний } \\
\text { - теорія і методика } \\
\text { картографування; } \\
\text { - атласне картографування } \\
\text { регіонів; } \\
\text { - картографування АПК; } \\
\text { - методика комп'ютерного } \\
\text { картографування; } \\
\text { - атласне картографування } \\
\text { великих міст. }\end{array}$ \\
\hline $\begin{array}{l}\text { екогеографічний } \\
\text { - теоретичні проблеми } \\
\text { екологічної географії; } \\
\text { - регіональні еколого- } \\
\text { географічні проблеми; } \\
\text { - екологічні проблеми } \\
\text { природокористування; } \\
\text { - географія природних ресурсів і } \\
\text { природокористування; } \\
\text { - моделювання економіко- } \\
\text { екологічних ситуацій; } \\
\text { - екологічні проблеми поселень; } \\
\text { - медико-географічний аналіз і } \\
\text { синтез. }\end{array}$ & $\begin{array}{l}\text { математико-географічний } \\
\text { - теоретичні проблеми } \\
\text { математизації суспільної } \\
\text { географії; } \\
\text { - багатовимірний } \\
\text { (факторний) аналіз; } \\
\text { - математико-карто- } \\
\text { графічне моделювання } \\
\text { господарських комплексів; } \\
\text { - математичний аналіз } \\
\text { економіко-географічних } \\
\text { об'єктів і процесів; } \\
\text { - геоінформаційне } \\
\text { моделювання суспільних } \\
\text { систем і процесів. }\end{array}$ & $\begin{array}{l}\text { історія географії, історична } \\
\text { географія (ІГ) } \\
\text { - теоретичні проблеми історії } \\
\text { географії та ІГ; } \\
\text { - історія географії України; } \\
\text { - історія української суспільної } \\
\text { географії; } \\
\text { - історія суспільної географії } \\
\text { Галичини; } \\
\text { - історія української і } \\
\text { польської суспільної географії; } \\
\text { - історія географії у } \\
\text { Львівському університеті; } \\
\text { - історична географія } \\
\text { населення і поселень. }\end{array}$ \\
\hline
\end{tabular}

Рис. 1. Структура загально- і суспільно-географічних досліджень львівських учених

функціонування різних типів грунтів в умовах диференційованого багатогалузевого їхнього використання та глобальних змін клімату; польове і геоінформаційне картографування стану грунтів та ефективності використання земельних ресурсів, моделювання і прогнозування його змін, розвитку деградаційних процесів; обгрунтування ресурсозберігаючих технологій використання 
Розвиток географічної науки у Львові за роки незалежності...

ISSN 2078-6441. Вісник Львівського університету. Серія географічна. 2013. Випуск 46

\begin{tabular}{|c|c|c|}
\hline $\begin{array}{l}\text { геоморфологічний } \\
\text { - теоретико-методологічні про- } \\
\text { блеми геоморфологїі, вивчення } \\
\text { генези і будови рельєфу; } \\
\text { - вивчення екзогенних та } \\
\text { ендогенних процесів; } \\
\text { - вивчення морфоструктури і } \\
\text { морфоскульптури; } \\
\text { - дослідження регіональних } \\
\text { геоморфологічних проблем; } \\
\text { - вивчення будови річкових долин } \\
\text { і річкових систем; } \\
\text { - вивчення будови і рис } \\
\text { плейстоценових відкладів; } \\
\text { - палеогеографія плейстоцену; } \\
\text { - інженерно-геоморфологічні } \\
\text { дослідження міст; } \\
\text { - геоморфологічне дешифрування } \\
\text { даних ДзЗ; } \\
\text { - еколого-геоморфологічні } \\
\text { дослідження регіонів; } \\
\text { - стаціонарні та експериментальні } \\
\text { дослідження сучасного } \\
\text { морфогенезу; } \\
\text { - природоохоронно-геоморфо- } \\
\text { логічний аналіз; } \\
\text { - геоморфологічне районування; } \\
\text { - геоморфологічне картування; } \\
\text { - історія геоморфологічних } \\
\text { досліджень. }\end{array}$ & $\begin{array}{l}\quad \begin{array}{l}\text { геоекологічний (еколого- } \\
\text { географічний) }\end{array} \\
\text { - теоретико-методичні } \\
\text { проблеми геоекології; } \\
\text { - регіонально-геоекологічні } \\
\text { (Карпати, Поділля, Полісся) } \\
\text { дослідження; } \\
\text { - галузево-екологічні } \\
\text { дослідження; } \\
\text { - компонентно-екологічні } \\
\text { дослідження; } \\
\text { - просторово-часова динаміка } \\
\text { геоекологічного стану річок, } \\
\text { озер, водосховищ, лісових, } \\
\text { аграрних, гірничо- } \\
\text { промислових ландшафтів; } \\
\text { - геоекологія стихійних явищ і } \\
\text { процесів; } \\
\text { - урбогеоекологічні } \\
\text { дослідження; } \\
\text { - геоекологічні дослідження } \\
\text { річкових долин і басейнів; } \\
\text { - медико-географічні дослід- } \\
\text { ження; } \\
\text { - геоекологічний моніторинг; } \\
\text { - геоекологічне районування. }\end{array}$ & \begin{tabular}{l}
\multicolumn{1}{c}{ ландшафтний } \\
- польові ландшафтні дослід- \\
ження і картографування; \\
- ландшафтно-геофізичні \\
дослідження (Карпати, Роз- \\
точчя); \\
- ландшафтно-екологічні \\
дослідження регіонів України; \\
- гідрометеорологічні \\
дослідження Західної України; \\
- лісопатологічні дослідження \\
Карпат; \\
- геоінформаційні системи в \\
ландшафтознавстві; \\
- дешифрування даних дзЗ; \\
- ландшафтно-екологічний \\
моніторинг та експертиза; \\
- стаціонарні геофізичні дослід- \\
ження геосистем; \\
- геохімічні дослідження \\
геосистем; \\
- урболандшафтні дослідження; \\
- ландшафтно-топонімічні \\
дослідження; \\
- оцінювання вітро- і водо- \\
енергетичного потенціалу \\
регіону; \\
- фізико-географічне і \\
ландшафтне районування.
\end{tabular} \\
\hline & $\begin{array}{c}\boldsymbol{4} \\
\text { Напрями природничо- } \\
\text { географічних досліджень }\end{array}$ & \\
\hline $\begin{array}{l}\text { гідрометеорологічний } \\
\text { - дослідження стоку води, наносів і } \\
\text { розчинених у речовин; } \\
\text { - моделювання розвитку повеней і } \\
\text { паводків у річках регіону; } \\
\text { - вивчення інтенсивності роз-витку } \\
\text { схилових і руслових процесів; } \\
\text { - дослідження екстремальних } \\
\text { гідрометеорологічних явищ; } \\
\text { - визначення тенденцій змін стоку } \\
\text { води і наносів у річках; } \\
\text { - гідроекологічний аналіз водойм; } \\
\text { - моніторинг екологічного стану } \\
\text { річок і водойм; } \\
\text { - структурний аналіз річкових } \\
\text { систем; } \\
\text { - дослідження процесів деграда-ції } \\
\text { малих річок; } \\
\text { - обгрунтування водоохоронних } \\
\text { заходів; } \\
\text { - лімногеографічні дослідження; } \\
\text { - аналіз вітроенергетичного } \\
\text { потенціалу; } \\
\text { - аналіз агрометеорологічного } \\
\text { потенціалу землеробства. }\end{array}$ & $\begin{array}{l}\text { біогеографічний } \\
\text { - географія рослин; } \\
\text { - географія тварин; } \\
\text { - географія біоценозів; } \\
\text { - географія зооценозів; } \\
\text { - географія шкідників лісу; } \\
\text { - географія хвороб лісу; } \\
\text { - географія біотичних } \\
\text { природно-заповідних } \\
\text { об'єктів; } \\
\text { - біогеографія інвазій і } \\
\text { сукцесій; } \\
\text { - іхтіологічні дослідження; } \\
\text { - орнітологічні дослід-ження; } \\
\text { - природоохоронні } \\
\text { дослідження; } \\
\text { - проблеми формування } \\
\text { екомереж; } \\
\text { - освітньо-біогеографічна } \\
\text { діяльність; } \\
\text { - біогеографічне } \\
\text { районування. }\end{array}$ & $\begin{array}{l}\quad \text { географо-грунтознавчий } \\
\text { - картографування грунтів; } \\
\text { - генетико-грунтознавчі } \\
\text { дослідження; } \\
\text { - географія грунтів Західного } \\
\text { регіону України; } \\
\text { - структура грунтового покриву; } \\
\text { - оцінювання стійкості грунтів; } \\
\text { - екологічні проблеми } \\
\text { землекористування; } \\
\text { - моніторинг грунтів; } \\
\text { - консервація деградованих } \\
\text { грунтів; } \\
\text { - аналіз антропогенної } \\
\text { трансформації грунтів; } \\
\text { - грунти урболандшафтів; } \\
\text { - аналіз чинників } \\
\text { грунтоутворення; } \\
\text { - моделювання ерозії грунтів; } \\
\text { - земельно-кадастрові дослід- } \\
\text { ження; } \\
\text { - агрокліматичні та } \\
\text { агроекологічні дослідження; } \\
\text { - історія грунтознавства. }\end{array}$ \\
\hline
\end{tabular}

Рис. 2. Структура природничо-географічних досліджень львівських географів земель, нових підходів до збереження і відтворення їхньої родючості, вирішення питань оптимізації землекористування в умовах трансформування суспільних відносин та ін. 


\begin{tabular}{|c|c|}
\hline Природоохоронні галузево-географічні & Природоохоронні комплексно-географічні \\
\hline $\begin{array}{l}\text { теоретичні проблеми природоохоронних } \\
\text { галузево-географічних досліджень (ПГГД) }\end{array}$ & $\begin{array}{l}\text { теоретичні проблеми природоохоронних } \\
\text { комплексно-географічних досліджень (ПКГД) }\end{array}$ \\
\hline питання методики ПГГД & проблеми методики ПКГД \\
\hline $\begin{array}{l}\text { проблеми природоохоронного картографування } \\
\text { компонентів ландшафту }\end{array}$ & $\begin{array}{l}\text { питання природоохоронного картографування } \\
\text { ландшафтних систем }\end{array}$ \\
\hline $\begin{array}{l}\text { проблеми створення і забезпечення } \\
\text { функціонування компонентних } \\
\text { природоохоронних об'єктів }\end{array}$ & $\begin{array}{l}\text { питання, пов'язані з обгрунтуванням створення } \\
\text { комплексних природоохоронних об’єктів }\end{array}$ \\
\hline $\begin{array}{l}\text { питання інвентаризації і кадастру компонентних } \\
\text { природоохоронних об'єктів }\end{array}$ & $\begin{array}{l}\text { проблеми картографічної інвентаризації і } \\
\text { паспортизації комплексних природоохоронних } \\
\text { об'єктів }\end{array}$ \\
\hline $\begin{array}{l}\text { проблеми моніторингу стану цінних у } \\
\text { природоохоронному відношенні компонентів } \\
\text { ландшафту }\end{array}$ & $\begin{array}{l}\text { питання, пов'язані з моніторингом } \\
\text { природозаповідних та антропогенних ландшафтів }\end{array}$ \\
\hline $\begin{array}{l}\text { питання, пов'язані з оптимізацією існуючої } \\
\text { мережі природоохоронних об'єктів }\end{array}$ & $\begin{array}{l}\text { проблеми, пов'язані з оптимізацією сучасного } \\
\text { стану комплексних (геопросторових) } \\
\text { природоохоронних об'єктів у різних регіонах }\end{array}$ \\
\hline $\begin{array}{l}\text { проблеми формування компонентних складових } \\
\text { сучасної екомережі }\end{array}$ & $\begin{array}{l}\text { проблеми формування екомережі як поєднання } \\
\text { точкових, площинних і лінійних об’єктів }\end{array}$ \\
\hline $\begin{array}{l}\text { проблеми законодавчого та управлінського } \\
\text { забезпечення охорони компонентів НПС }\end{array}$ & $\begin{array}{l}\text { проблеми законодавчого та управлінського } \\
\text { забезпечення природоохоронної справи }\end{array}$ \\
\hline питання природоохоронно-освітньої діяльності & $\begin{array}{l}\text { питання природоохоронно-освітньої, } \\
\text { природоохоронно-рекламної діяльності }\end{array}$ \\
\hline & $\begin{array}{l}\text { Напрями туристично-рекреаційних } \\
\text { і природоохоронних досліджень }\end{array}$ \\
\hline Дослідження туризму і туристичної діяльності & Комплексні дослідження сфери рекреації \\
\hline теоретичні проблеми досліджень сфери туризму & теоретичні питання аналізу сфери рекреації \\
\hline питання методики досліджень туризму & методичні питання досліджень рекреації \\
\hline дидактичні проблеми туристичної освіти & дидактичні проблеми рекреаційної освіти \\
\hline екоосвітні питання туристичної діяльності & екоосвітні питання рекреаційної діяльності \\
\hline екологічні проблеми туризму & екологічні проблеми рекреації \\
\hline проблеми сільського, зеленого туризму & $\begin{array}{l}\text { проблеми досліджень бальнеологічних ресурсів і } \\
\text { бальнеологічної діяльності }\end{array}$ \\
\hline географія туризму & географія рекреації \\
\hline історія туристичної діяльності & історія розвитку рекреаційної діяльності \\
\hline
\end{tabular}

Рис. 3. Структура туристично-рекреаційних і природоохоронних досліджень львівських географів

Наукова школа інженерної, екологічної та регіональної геоморфології заснована у 1950 р. на базі кафедри геоморфології. Засновник - д-р геогр. наук, проф. П. М. Цись. У роботі школи беруть участь д-р геогр. наук, проф. І. П. Ковальчук та канд. геогр. наук, проф. Я. С. Кравчук, проф. А. Б. Богуцький, д-ри наук, проф. М. Я. Сивий, В. І. Вишневський, Л. П. Царик, д-р наук, доц. Л. Ф. Дубіс, доц. Р. М. Гнатюк, Н. І. Карпенко, Я. Б. Хомин, І. М. Сіренко, 
Г. Б. Байрак, П. М. Горішний, О. В. Колтун, М. Б. Іваник, А. М. Яцишин, Р. Я. Дмитрук, Є. А. Іванов, А. В. Михнович, О. В. Пилипович, М. А. Петровська, Л. П. Курганевич, В. М. Шушняк, Т. С. Павловська, М. А. Федонюк, О. С. Терещук та ін. (понад 40 кандидатів наук). Учені розробили концепції екологічної геоморфології, стаціонарних досліджень сучасного морфогенезу, регіонального геоморфологічного аналізу, інженерно-геоморфологічного картографування, аналізу трансформаційних процесів у річкових системах, геоекологічних досліджень гірничопромислових геосистем, палеогеографічних реконструкцій подій плейстоцену; опубліковали серію підручників і навчальних посібників (понад десять), монографій (понад 40) та статей у вітчизняних і зарубіжних виданнях.

Перспективи розвитку цієї наукової школи пов'язуємо з такими чинниками: роботою над розробкою теоретичних і прикладних проблем антропогенної, біогенної, динамічної, екологічної, кліматичної, рекреаційної, геосоціальної геоморфології; розробкою і ширшим упровадженням у дослідження нових методів і технологій палеогеографічних реконструкцій та геоморфологічних прогнозів (з урахуванням глобальних змін клімату та інтенсифікації антропогенних впливів на навколишне середовище); оцінюванням ризиків прояву екстремальних геоморфологічних процесів та створюваних ними загроз (для людини, угідь і комунікацій); вивченням динаміки екзогенних процесів стаціонарними, дистанційними, геоінформаційними методами; прогнозуванням змін станів рельєфу та розвитку морфодинамічних процесів; розробкою проектів національних природних парків, геопарків, природних заповідників та ін.

Наукову школу комплексної територіальної організації суспільства заснував на кафедрі економічної (тепер економічної і соціальної) географії у 19451950 рр. д-р геогр. наук, проф. О. Т. Ващенко. Відомими представниками цієї школи стали випускники кафедри: проф. Ф. Д. Заставний, Б. М. Яремчишин, М. Д. Пістун, О. І. Шаблій, О. Г. Топчієв, С. М. Писаренко, С. І. Іщук, О. В. Заставецька, М. 3. Мальський, М. П. Мальська, В. П. Нагірна, Л. Т. Шевчук, М. С. Дністрянський, І. І. Ровенчак, Р. М. Лозинський, доц. М. М. Книш, С. П. Кузик, М. І. Білецький, М. Р. Влах, В. С. Грицевич та ін. Підготовлено близько 20 докторів та 80 кандидатів наук. Сучасним лідером школи $є$ заслужений професор Львівського університету, д-р геогр. наук, проф., завідувач кафедри O. I. Шаблій. До здобутків школи належать теоретичні концепції суспільної та економічної географії, розробки в галузі географічного українознавства, геополітики, політичної географії, етногеографії, географії населення, сфери послуг, туризму, культури, соціальних негараздів, рекреаційної географії, країнознавства, краєзнавства та ін., десятки посібників і підручників, монографій, серія оригінальних атласів.

На наш погляд, перспективними напрямами розвитку цієї потужної школи можуть бути: поглиблення методології суспільно-географічних досліджень трансформаційних процесів, що відбуваються в українському суспільстві; дослідження природного, виробничого, демографічного, інтелектуального, інноваційного, інвестиційного потенціалу розвитку України; удосконалення концеп- 
цій суспільно-географічної глобалістики і глобальної географії; дослідження проблем депресивності регіонів, обгрунтування технологій і механізмів ii подолання; пошуки оптимальних моделей розвитку євроінтеграційних процесів; розвиток таких напрямів досліджень, як: еколого-економічні проблеми природокористування; географічні засади формування успішного соціально орієнтованого, демократичного суспільства; формування географічних засад територіального розпланування (обласний, районний та поселенський рівні) й управління; завдання екологізації, стандартизації суспільно-географічних досліджень; розвиток агрогеграфічної концепції; розвиток досліджень у сфері формування інформаційної цивілізації, створення та забезпечення оптимального функціонування Grid-iнфраструктури (створення комп'ютерних кластерів і швидкісних ліній для передачі інформації користувачам) на різних рівнях від локального до глобального; питання створення гнучкої територіальної організації виробництва, в тім числі за суперсучасними технологіями (так званого адитивного виробництва), дослідження проблем географії спадщини; дослідження людського капіталу, інституційного середовища, агломераційних процесів; гуманістичних і соціальних процесів тощо.

Наукову школу ландшафтознавства заснував д-р геогр. наук, проф. Каленик Іванович Геренчук у 1954 р. на базі кафедри фізичної географії. У 1984 1994 рр. школою керував д-р геогр. наук, проф. Г. П. Міллер. Представниками наукової школи є кандидат географічних наук, проф. С. І. Кукурудза, д-р геогр. наук, проф. В. М. Петлін, д-р геогр. наук, проф. А. В. Мельник, кандидати географічних наук, доценти Б. П. Муха, О. М. Федірко, С. А. Іванов, В. І. Біланюк, П. М. Шубер, О. Б. Загульська. Підготовлено чотири доктори і 35 кандидатів наук. До здобутків школи належить: поглиблення вчення про морфологію гірських і рівнинних ландшафтів, розроблення принципів їхньої класифікації та фізико-географічного районування; визначення закономірностей будови і функціонування ландшафтних фацій; розроблення концепції ландшафтно-екологічного аналізу гірських регіонів; формування ландшафтних засад оптимізації ведення сільського і лісового господарства, рекреації, заповідної справи; пропозиції з удосконалення системи моніторингу ландшафтів, геоінформаційного картографування ландшафтів і земних покривів; моніторинг змін клімату; обгрунтування методології, програми стаціонарних ландшафтногеофізичних досліджень тощо. Про успіхи школи свідчать два десятки монографій, серія навчальних посібників і підручників, концепції гірського, екологічного та експериментального ландшафтознавста.

Перспективи розвитку школи пов'язуємо 3 геоінформаційним картографуванням і моделюванням станів ландшафтних систем; стаціонарним i дистанційним вивченням функціонування геосистем різних рангів та рівнів антропізації; оцінюванням ресурсного потенціалу, придатності ландшафтних систем для їх освоєння різними видами господарської діяльності; вирішенням проблем землекористування, лісокористування, рекреаційної географії на ландшафтно-екологічних засадах та ін. 
Крім того, формуються нові наукові школи: природоохоронних досліджень (проф. С. І. Кукурудза, проф. І. М. Волошин, проф. М. М. Назарук, доц. В. П. Брусак, Б. В. Сенчина, І. Б. Койнова, І. М. Рожко, В. М. Шушняк, ст. викладач Ю. В. Зінько та ін.) і туризму та рекреаиії (д-р економ. наук, проф. М. П. Мальська, д-р геогр. наук, проф. Р. М. Лозинський, доц. А. С. Ковальчук, М. Й. Рутинський, О. Ю. Бордун, М. З. Гамкало, І. Г. Пандяк, П. Р. Романів, Д. А. Каднічанський, Н. Л. Мандюк, А. М. Манько, В. Р. Монастирський, ст. викладач Ю. В. Зінько та ін.). Школа туризму і рекреації розвивається особливо інтенсивно, про що свідчать великі конкурси вступників на цю спеціальність, чисельні навчальні посібники і підручники, підготовлені ㄲi представниками, а також участь учених у міжнародних грантових програмах $\mathrm{i}$ проектах, у розробці програм розвитку туризму в Карпатському регіоні та Україні загалом тощо.

Перспективні напрями львівської географії.

До найважливіших 3 них належать: 1) удосконалення концепції геополітичних і політико-географічних досліджень, узагальнення отриманих результатів у вигляді монографій, підручників, навчальних посібників, статей; 2) розвиток досліджень у галузях географічного українознавства, краєзнавства, географії культури та етногеографії, формування наукової школи географічного українознавства і краєзнавства; 3) формування наукових засад географії суспільних негараздів, наповнення цього напряму досліджень конкретними результатами; 4) дослідження в галузі людського розвитку; 5) дослідження процесів глобалізації і регіоналізації, маргіналізації одних і бурхливого розвитку інших територій, вивчення особливостей трансформування регіональних соціумів; 6) виявлення загроз, ризиків суспільств різних типів і прогнозування можливих наслідків цих процесів; 7) пошуки шляхів вирішення проблем українського села на етапі трансформації суспільних відносин; 8) пошуки оптимальних моделей розвитку євроінтеграційних процесів, демократизації та інформатизації усіх сфер функціонування української держави; 9) формування концепції зрівноваженого розвитку природно-господарських систем регіону; 10) розробка концепції регіонального землекористування, збереження i відтворення земельних, лісових та водних ресурсів 3 урахуванням реалій трансформації суспільних відносин; 11) геоінформаційно-картографічне моделювання стану і змін природних, господарських, етнографічних, суспільних систем і процесів; 12) удосконалення методології, методик та алгоритмів геоекологічних, грунтово-екологічних, ландшафтно-екологічних, еколого-геоморфологічних і гідроекологічних досліджень; 13) вивчення проблем туристичної галузі господарства, формування концепції і стратегії розвитку туризму та рекреації в Карпатському регіоні; 14) розвиток досліджень в галузі екологічної безпеки, ризиків природокористування (у т. ч. у зв'язку з глобальними змінами клімату); 15) розвиток морфодинамічних, інженерно-географічних, палеогеографічних досліджень; 16) розвиток концептуальних засад географічних інновацій; 17) розробка проблематики екосистемних послуг, поведінки України на внутрішньому і зовнішньому ринках цього виду послуг; 
$18)$ удосконалення науково-методичних засад i технологій конструктивногеографічних, ландшафтно-планувальних, екоосвітніх, природоохоронних, процесорегулювальних та інших видів прикладних досліджень.

Отже, погляд на стан львівської географії, іiі кадровий потенціал, матеріально-технічну і фінансову базу досліджень, урахування траєкторій розвитку географічної науки в Україні і світі свідчить не лише про великі перспективи iii розвитку, а й про певні проблеми, ризики, небезпеки. До них можна зачислити: 1) вікова диспропорція у науково-дослідницькому потенціалі львівської географії (мало молодих докторів наук з високим творчо-продуктивним потенціалом), яка з часом може призвести до зниження авторитету львівської школи; 2) уповільнення темпів продукування перспективних наукових ідей, мала кількість публікацій в авторитетних закордонних виданнях; 3) недостатній рівень математизації усіх галузей географії; 4) деяка інерційність у сприйнятті модерних ідей сучасної світової географії порівняно $з$ іншими науковими центрами (Київським, Кримським); 4) відсутність у структурі факультету кафедр, які б забезпечували підготовку фахівців гідрометеорологічного, геодезично-картографічного і землевпорядного профілю; 5) відставання від передових шкіл світової географії у матеріально-технічному (лабораторному, комп'ютерному, технічному) та фінансовому забезпеченні науково-дослідних робіт; 6) зниження освітнього рівня випускників середньої школи, комерціалізацію вищої освіти, зниження якості викладання у ВНЗ і рівня готовності випускників-географів (у т. ч. й аспірантів) до наукової і практичної роботи; 7) необхідність посилення зв'язків з виробництвом, у тім числі через удосконалення навчальних планів та запрошення працівників виробництва до викладання практично орієнтованих дисциплін тощо.

Подолання цих проблем - справа львівських географів. Сподіватимемося на успішне їхнє вирішення і посилення авторитету як Франкового університету, так і львівської географії у науковому світі.

1. Біланюк В. Географічна освіта, наука і практика у Львівському університеті: історія i сучасність / В. Біланюк, С. Іванов // Географічна наука і практика: виклики епохи: Матер. міжнар. наук. конференції, присвяченої 130-річчю географії у Львівському університеті (16-18 травня 2013 р.) / [Відп. редактори: доц. В. І. Біланюк, доц. Є. А. Іванов]. У 3-х томах. - Львів: Видавничий центр ЛНУ імені Івана Франка, 2013. - Т. 1. C. $12-18$.

2. Ващенко П. Т. Розвиток географії у Львівському університеті (до 300-річчя з дня заснування) / П. Т. Ващенко, К. І. Геренчук, Г. А. Зільбер, П. М. Цись // Вісник Львівського ун-ту. Сер. геогр. - 1962. - Вип. 1. - С. 3-12.

3. Ващенко A. T. Географической науке во Львовском университете - 100 лет / А. Т. Ващенко, К. И. Геренчук, Я. С. Кравчук, Г. П. Миллер // Вестник Львовского ун-та. Сер. геогр. Вып 14. - Львов, 1984.

4. Влах М. Львівська суспільно-географічна школа: еволюція агрогеографічної концепції / М. Влах, Т. Коропецька // Географічна наука і практика: виклики епохи: матер. 
міжнар. наук. конференції, присвяченої 130-річчю географії у Львівському університеті (16-18 травня 2013 р.) / [Відп. редактори: доц. В. І. Біланюк, доц. С. А. Іванов]. Львів: Видавничий центр ЛНУ імені Івана Франка, 2013. - Т. 1. - С. 34-38.

5. Ковальчук I. Вектори розвитку української геоморфології / I. Ковальчук // Геоморфологічні дослідження в Україні: минуле, сучасне і майбутнє: матер. міжнар. конф. - Львів: ВЦ ЛНУ імені Івана Франка, 2001. - С. 192-200.

6. Ковальчук I. Наукові школи української геоморфології / І. Ковальчук // Сучасні проблеми і тенденції розвитку географічної науки: матер. міжнар. конф. до 120-річчя географії у Львівському університеті (24-26 вересня 2003 р.). - Львів, 2003. - С. 58-61.

7. Ковальчук I. Професор Петро Цись: внесок у розвиток української геоморфології / I. Ковальчук // Проблеми геоморфології і палеогеографії Українських Карпат і прилеглих територій: матер. міжнар. семін., присвяченого 90-річчю від дня народження засновника кафедри геоморфології і палеогеографії професора Петра Цися (30 вересня3 жовтня 2004 р.). - Львів: ВЦ ЛНУ імені Івана Франка, 2004. - С. 24-46.

8. Ковальчук I. Українська геоморфологія на межі тисячоліть: здобутки, проблеми, перспективи / І. Ковальчук // Фізична географія та геоморфологія. - К.: ВГЛ “Обрії”, 2005. - Вип. 49. - С. 10-17.

9. Ковальчук I. Кафедра геоморфології Львівського національного університету: історія, сьогодення, перспективи / І. Ковальчук, Я. Кравчук // Історія української географії. Всеукраїнський науково-теоретичний часопис. - Тернопіль: Підручники і посібники, 2000. - Вип. 2. - С. 34-42.

10. Кравчук Я. С. Географія у Львівському університеті / Я. С. Кравчук // Проблеми географії України: матер. наук. конф. (25-27 жовтня 1994 р.). - Львів, 1994. - С. 3-4.

11. Кравчук Я. С. Львівська географія за 120 років: історія, персоналії, наукові напрями, школи / Я. С. Кравчук // Сучасні проблеми і тенденції розвитку географічної науки: матер. міжнар. конф. до 120-річчя географії у Львівському університеті (24-26 вересня 2003 р.). - Львів: ВЦ ЛНУ імені Івана Франка, 2004. - С. 3-16.

12. Кравчук $Я$. С. Географія у Львівському національному університеті імені Івана Франка: історія і сучасність / Я. С. Кравчук, Я. Б. Хомин // Фізична географія та геоморфологія. - К.: ВГЛ “Обрії, 2009. - Вип. 55. - С. 317-330.

13. Кравчук $Я$. Розвиток грунтознавчої науки у Львівському державному університеті ім. Івана Франка / Я. Кравчук, С. Позняк, П. Климович, М. Кіт // Вісник Львівського унту. Сер. геогр. - Львів, 1998. - Вип. 23. Генезис, географія і екологія грунтів. - С. 3-9.

14. Кравчук Я. С. Геоморфологія і палеогеографія у Львівському університеті (19612011) / Я. С. Кравчук // Вісн. Львів. ун-ту. Сер. геогр. - 2012. -Вип. 40. -Ч. 1. - С. 32-45.

15. Мальська М. Основні етапи та напрями розвитку кафедри туризму Львівського національного університету імені Івана Франка / М. Мальська, М. Рутинський // Вісн. Львів. ун-ту. Сер. геогр. - 2012. - Вип. 40. - Ч. 1. - С. 86-100.

16. Мельник A. Львівська школа ландшафтознавства / А. Мельник, Б. Муха, О. Федірко // Проблеми і тенденції розвитку географічної науки: матер. міжнар. конф. до 120-річчя географії у Львівському університеті. - Львів, 2003. - С. 28-32.

17. Муха Б. Кафедра фізичної географії Львівського національного університету. Історія та персоналії: зб. / Б. Муха. - Львів: ВЦ ЛНУ імені Івана Франка, 2004. - 430 с.

18. Новітня українська суспільна географія. Хрестоматія / Упоряд. та автор біографічних статей проф. О. Шаблій. - Львів: ВЦ ЛНУ імені Івана Франка, 2007. - 1000 с. 19. Позняк С. Роль кафедри грунтознавства і географії грунтів у становленні наукової школи грунтознавства Західного регіону України / С. Позняк, О. Бонішко // Вісн. Львів. ун-ту. Сер. геогр. -2012. - Вип. 40. - Ч. 1. - С. 63-77. 
20. Професор Опанас (Афанасій) Ващенко / Упорядник О. Шаблій. - Львів: ВЦ ЛНУ імені Івана Франка, 2001. - 233 с.

21. Рудниџький С. Фізична географія при кінці XIX століття / С. Рудницький // Збірник математично-природописно-лікарської секції НТШ. - Львів, 1903. - Т. 9. - С. 1-116. 22. Шаблій O. I. Суспільна географія: теорія, історія, українознавчі студії / О. І. Шаблій. - Львів: Львівський національний університет імені Івана Франка, 2001. -744с. 23. Шаблій $O$. Основи загальної суспільної географії: підручник / О. Шаблій. - Львів: ВЦ ЛНУ ім. Івана Франка, 2003. - 444 с.

24. Шаблій $O$. Львівська суспільно-географічна школа (до 60-річчя кафедри економічної і соціальної географії Львівського національного університету імені Івана Франка) / О. Шаблій. - Львів: ВЦ ЛНУ імені Івана Франка, 2004. - 168 с.

25. Шаблій О. I. Нові тенденції геопросторової організації інформаційного суспільства / O. I. Шаблій // Географічна наука і практика: виклики епохи: матер. міжнар. наук. конф., присвяченої 130-річчю географії у Львівському університеті (16-18 травня 2013 р.) / [Відп. редактори: доц. В. І. Біланюк, доц. С. А. Іванов]. У 3-х томах. - Львів: Видавничий центр ЛНУ імені Івана Франка, 2013. - Т. 1. - С. 25-30.

26. Harasimiuk K. Z dzijów uniwersytetskiej geografii Lwowskiej (lata 1882-1910) / K. Harasimiuk // Annales UMCS, vol. XLV, 16/Sektio B, 1989-1990.

27. Jahn A. Z Kleparova w Swjat szeroki / A. Jahn. - Wroclaw; Warszawa; Kraków, 1991. $332 \mathrm{~s}$.

Стаття: надійшла до редколегії 16.05.2013 доопрацьована 12.07.2013

прийнята до друку 25.09.2013

\section{DEVELOPMENT OF GEOGRAPHY IN UKRAINE SINCE INDEPENDENCE: STRUCTURE, SCHOOLS, ACHIEVEMENTS, CHALLENGES}

\section{Kovalchuk}

National University of Life and Environmental Sciences of Ukraine, Str. Vasyl'kivska, 17, Kyiv, 03040, Ukraine

The paper describes the background of Lviv geography at the end of XX-beginning of XXI century and the structure of geographical research Lviv scientists of this period. It is shown that the trajectory of development is determined by several factors: 1) the tradition of Lviv geography in which the main areas of research are natural-geographic, social, geographic and cartographic; 2) the influence of global geography of innovation in the development of Lviv geography; 3 ) existing scientific potential; 4) changes in society, his requests to geography, and changes in the research system and explore the world of technology and so on.

Within the geographical research, three areas of blocks were identified: 1) general, social and geographical research; 2) natural-geographical studies; 3) tourism and recreation and environmental studies. Each of these blocks in turn are allocated between four and eight research groups finding that further differentiated on 8-15 branches. The achievements and prospects of the four academic schools are described. Problem and promising areas of geographic research under the Lviv University geography are outlined.

Key words: Lviv geography, scientific schools, the structure of geographical research, the problem of Lviv geography. 


\section{РАЗВИТИЕ ГЕОГРАФИЧЕСКОЙ НАУКИ ВО ЛЬВОВЕ ЗА ГОДЫ НЕЗАВИСИМОСТИ УКРАИНЫ: СТРУКТУРА, НАУЧНЫЕ ШКОЛЫ, ДОСТИЖЕНИЯ, ПРОБЛЕМЫ}

\section{И. Ковальчук}

Наииональный университет биоресурсов и природопользования Украины, ул. Васильковская, 17, г. Киев, 03040, Украина

Охарактеризовано предпосылки развития львовской географии в конце XXначале XXI века и структуру географических исследований львовских ученых этого периода. Показано, что траектория развития определялась несколькими факторами: 1) традициями львовской географии, в которой основными направлениями исследований были естественно-географические, общественно-географические и картографические; 2) влиянием инноваций мировой географии на развитие львовской географии; 3) существующим научным потенциалом; 4) изменениями в жизни общества, его запросами к географической науке; 5) изменениями исследовательского аппарата и технологий изучения окружающего мира и т. д.

В структуре географических исследований выделено три блока направлений: 1) общественно-географических исследований; 2) естественно-географических исследований; 3) туристско-рекреационных и природоохранных исследований. В каждом из этих блоков в свою очередь выделены от четырех до восьми групп исследовательского поиска, которые далее дифференцируются на 8-15 отраслей. Кратко охарактеризованы достижения и перспективы развития четырех научных школ. Выделены также проблемные вопросы и намечены перспективные направления развития географических исследований в рамках львовской университетской географии.

Ключевые слова: львовская география, научные школы, структура географических исследований, проблемы львовской географии. 